\title{
RECENZJA KSIĄŻKI MAGDALENY SZPUNAR, KULTURA CYFROWEGO NARCYZMU, WYDAWNICTWA AGH, KRAKÓW 2016, SS. 219
}

Przestrzeń wirtualna pozwala jednostkom na kreowanie rozmaitych wizerunków siebie, reprezentacji niekoniecznie wiernych pozainternetowej rzeczywistości. Obserwowane współcześnie nasycenie Internetu mechanizmami autopromocyjnymi nie tylko zwiększa tolerancję dla tych zachowań, ale też może spowodować, iż zostaną one uznane za obowiązujące. Wprowadzone przez Christophera Lascha pojęcie kultury narcyzmu można dziś z powodzeniem odnieść do świata wirtualnego. Specyfika internetowej komunikacji dodatkowo podsyca zachowania narcystyczne.

Najnowsza książka Magdaleny Szpunar - Kultura cyfrowego narcyzmu - poświęcona jest tym zjawiskom. Autorka zwraca uwagę, że choć mit o Narcyzie posiada wiele wersji, to jego figura pozostaje niezmienna. I to właśnie narcyzm, jej zdaniem, jest zasadniczym środkiem do opisu kondycji człowieka ponowoczesnego.

Magdalena Szpunar w sposób wyczerpujący przedstawia problemy jednostek i zbiorowości narcystycznych. Niejednokrotnie odwołuje się przy tym do Wilka stepowego Hermanna Hesse. Narcyzm nazywa tak, jak Hesse ujął zaburzenia umysłowe głównego bohatera swej książki: „chorobą epoki, neurozą całego pokolenia”. Autorka zwraca przy tym uwagę, że we współczesnej kulturze liczba neurotyków spada na rzecz narcyzów - rozpaczliwie szukających aprobaty, przez co czyniących autoprezentację jednym z najważniejszych aspektów ich życia. Ta swoista diagnoza współczesnego człowieka poparta jest badaniami licznych przedstawicieli rozmaitych dyscyplin naukowych. Podział na świat realny i wirtualny jest wobec tych rozważań wtórny. Badaczka słusznie bowiem zauważa, iż technologizacja codziennego życia powoduje wzajemne przenikanie tych sfer, stąd narcyzm nie jest jedynie domeną internautów, lecz przypadłością współczesnej kultury jako takiej. W swych rozważaniach Magdalena Szpunar nie rozstrzyga, czy to zorientowana narcystycznie kultura wymusza na jednostkach dostosowanie się do panującego kanonu, czy też jednostki narcystyczne kształtują kulturę na wzór siebie.

Analizując zjawisko narcyzmu, autorka bada wiele jego aspektów: konieczność sukcesu i powodzenia (nawet wyimaginowanego), maniakalne szukanie aprobaty, 
brak obiektywizmu, brak pokory, wybiórcze traktowanie rzeczywistości, a przy tym szczególne narażenie na doświadczenia lękowe. Przedstawiony zostaje paradoks jednostki narcystycznej, która z jednej strony afirmuje siebie i z góry uznaje swych sympatyków za osoby wartościowe, a pogardą darzy tych, którzy jej nie przyklaskują; zaś z drugiej strony posiada tak niską samoocenę, że nie wierzy w pochwały, a swych afirmatystów uważa za kłamców.

Kolejno w swej książce Magdalena Szpunar przybliża narcystyczną kulturę. Za Tomaszem Szlendakiem stwierdza, iż konsumpcjonizm socjalizuje coraz mniej do wspólnoty, a coraz bardziej do przedmiotów. Z kolei kultura amerykańska, zważywszy na jej ogromną presję na wysoką samoocenę, wydaje się socjalizować do narcyzmu. Kultura narcystyczna, do której, zdaniem autorki, przyczyniła się dominacja obrazu, kładzie akcent przede wszystkim na popularność, gdyż narcyz bez publiczności żyć nie potrafi. Badaczka nazywa Internet „,medium narcystycznym”, ponieważ preferuje on autoprezentację i preparowanie kreacji własnej osoby. Jej zdaniem brak autentyczności jest tu wtórny wobec popularności, a możliwość zaistnienia w sieciważniejsza niż jakość nadawanego komunikatu.

Powołując się na badania licznych autorów, M. Szpunar charakteryzuje sposób funkcjonowania jednostek narcystycznych w Internecie. Spędzają one więcej czasu na portalach społecznościowych; im bardziej są samotne, tym mocniej angażują się w komunikację online; często bardziej akceptują wykreowaną w Internecie ,ulepszoną wersję siebie" niż siebie samych z rzeczywistości pozainternetowej.

Rozważania te prowadzą autorkę ku dalszym wnioskom, a mianowicie, że współczesna, narcystyczna kultura cierpi na deficyt autentyczności. Jej brak pozornie ułatwia komunikację, lecz w istocie jest źródłem lęków. Z kolei manipulowanie wrażeniami czyni narcystyczny fałsz i ułudę podstawą międzyludzkich relacji. M. Szpunar dostrzega tutaj niepokojące zjawisko użytkowej szczerości. Do jego opisania posługuje się dwoma terminami: właśnie szczerością, rozumianą za Wacławem Branickim jako „wierność samemu sobie”, oraz autentycznością, która zniekształcana jest przez rozum. Szczerość uzyskuje charakter użytkowy, gdy wierna jest simulacrum - temu, co zostało spreparowane na użytek innych osób.

Deficyt pokory i imperatyw fałszu są, zdaniem badaczki, charakterystyczne dla współczesnej egocentrycznej kultury, do której opisania niezbędnym pojęciem wydaje się narcyzm. Zachodzące obecnie przemiany implikują kolejne zjawisko - kulturowy autyzm, czyli niezdolność do bezpośredniej komunikacji, głęboki introwertyzm i zainteresowanie jedynie własnym światem.

Kultura cyfrowego narcyzmu M. Szpunar to wyczerpująca pozycja, rzetelnie opisująca aktualne zjawiska kulturowe. Książka stanowi zwieńczenie dotychczasowego dorobku autorki, która po raz kolejny udowadnia głęboką znajomość materii medioznawczej. Badaczka zawsze skrupulatnie definiuje pojęcia, którymi operuje, nie pozostawiając miejsca dla niedomówień. Wprowadza też własne terminy, takie jak np. „media zerowe”. Brak tu lakonicznych określeń i ogólnikowych teorii. Śmiałe i precyzyjnie formułowane tezy przeplatane są ogromem odwołań do prac naukowych $\mathrm{z}$ rozmaitych dyscyplin humanistyki. Tym samym praca ta wymaga od czytelnika 
pewnych kwalifikacji, by pośród ogromu prezentowanej wiedzy mógł wychwycić najważniejsze, najbardziej aktualne tezy.

W czasach, w których „być, to znaczy istnieć online” - jak mówi Magdalena Szpunar - zmiany w procesach komunikacji i autoprezentacji nadały kulturze nowy, narcystyczno-autystyczny charakter. Kultura cyfrowego narcyzmu ten obecny stan wnikliwie analizuje i szczegółowo charakteryzuje. Brak jednak w tekście wartościowania zjawisk, co czyni tę książkę nie tylko aktualną, ale też obiektywną pozycją, z którą każdy zainteresowany zagadnieniem nowych mediów powinien się zapoznać. 